\title{
NORMATIVE DIMENSIONS OF SPEECH ACTS: EXPLORATORY STUDY IN SASAK SPEECH COMMUNITY
}

\section{(DIMENSI NORMATIF TINDAKAN BERBAHASA: KAJIAN EKSPLORASI DALAM KOMUNITAS UJARAN SASAK)}

\author{
Muh. Junaidi \\ UNW Mataram
}

Diterima: 9 April 2018; Direvisi: 9 Mei 2018; Disetujui: 21 Mei 2018

\begin{abstract}
This study investigates normative dimensions of speech acts. It analyzes the nature of normative dimension of speech acts.To get empirical data, 9 participants were chosen as sources of spoken language data: 2 tuan guru giving speeches in formal contexts; and 7 people engaging in casual conversations in informal context. To collect data, observation and voice recording was used. Prior to analysis, the data were transcribed, labeled and classified according to categories that appeared from the data. Findings reveal and advocate the normative and moral dimensions of speech acts generated from agent's change normative standing to hearers in terms of right, obligation and responsibility. As a result, the study argues that moral values embedded in speech act performance such honesty, truth, selfcontrol and respect, obedience and so forth could be taught in order to foster children good character development in comprehensive ways including moral reasoning, affection and behaviors. For that reason, moral values teaching based on speech act normativity and morality could be used as an arena for bearing good character corresponding to the process of acquiring of the first language or learning the second/foreign language. This could be a starting point for teaching moral competence through language institution that are more affordable, accessible and learnable for all rational human being all over the world. Furthermore, those moral values might be the foundation for moral action of children to bear the awareness of good interpersonal or intersubjective relationship. Based on the limitation of the study, it needs to hold further study as to the practical model of teaching moral values on the bases of moral values embedded in performing speech acts.
\end{abstract}

Keywords: speech acts, normative dimensions, moral teaching

\begin{abstract}
Abstrak
Kajian ini menelaah tentang karakter dimensi normatif tindakan berbahasa. Data empiris diperoleh dengan melibatkan 9 partisipan, yakni 2 tuan guru yang memberikan ceramah dalam konteks formal dan 7 orang yang terlibat percakapan kasual dalam konteks informal. Data dikumpulkan melalui observasi dan rekaman suara. Sebelum analisa, data tersebut ditranskripsi, dilabeli dan diklasifikasikan. Kajian ini mengungkapkan dan mendukung adanya dimensi normatif dan moral tindakan berbahasa yang dibentuk dari perubahan kedudukan normatif pembicara dan pendengar terkait hak, kewajiban dan tanggungjawab. Kajian ini mendukung bahwa dimensi normatif dan nilai moral yang melekat dalam setiap tindakan berbahasa seperti, kejujuran, kebenaran, komitmen, tanggungjawab, kontrol diri, saling menghargai dan lain-lain yang bisa diajarkan dalam pengembangan karakter anak yang bermoral dengan cara yang
\end{abstract}


komprehensif meliputi penalaran moral, afeksi dan tindakan. Oleh sebab itulah, pengajaran nilai-nilai moral berbasis moralitas dan normativitas tindakan berbahasa bisa digunakan sebagai arena pendidikan karakter atau nilai. Ini bisa menjadi langkah awal pengajaran kompetensi moral melalui instiusi bahasa. Di samping itu, nilai-nilai moral tersebut merupakan fondasi dalam tindakan anak yang bermoral untuk membangun kesadaran interpersonal anak yang baik. Berdasarkan keterbatasan kajian ini, diperlukan kajian lebih lanjut tentang model praktis pengajaran nilai-nilai moral berbasis dimensi normatif dan moral yang inheren dalam setiap tindakan berbahasa.

Kata kunci: tindakan berbasa, dimensi normatif, pembelajaran moral

\section{Introduction}

Language is not only a means of communication, but also a means of value or moral education. The latter nature of language in the sense of normative dimensions of speech acts has attracted language philosophers and linguists (Searle, 2001; Alston, 2000; Cuneo, 2014) to delve into such dimensions. Based on universal nature of language, it is in need of studying such normative dimensions of Sasak language.

Sasak language is mostly spoken in Lombok Island, West Nusa Tenggara, Indonesia, near to the East region of Bali. Sasak language has five dialects: a) Ngeno-ngene, in the Central West coast and the Central East to the North East coast; b) Meno-mene, around Puyung and Praya, and in the East Lombok; c) Ngeto-ngete, around Suralaga, and Sembalun in the North East: d) Kuto-kute, around Bayan region and in the North; and e) Meriaqmeriku, in the South central area around Bonjeruk, and Sengkol.

This study concerned their nature of normative and moral dimensions of illocutionary acts by using samples of Tuan Guru (a competently-religious teacher who are colletively recognized and accepted by society)speeches and casual conversations of Meno-mene dialect in the South Sikur village. In this area, local people speak Sasak language as their mother tongue and Indonesian as their second language.
The South Sikur villagers are bilingual community. Sasak language, Meno-mene dialect, is used in daily communication with one another at home, in and around the Mosque, and other domains. These people speak Indonesian in formal setting and at school. Indonesian is also used when meeting with new comers.

Language is an utterance that has a communicative and performative function. This fact is Austin's underlying assumption in generating his speech act theory. A locutionary act is produced by saying something and an illocutionary act is by doing something. Austin's initiation led opponents and proponents to dispute on the nature and elements of speech acts. One of the most argued unit is the nature of illocutionary acts. Some believe illocutionary act (IA) is the basis of rule or conventional act such as Austin (1962), Sbisa (2001), Searle (1969), and Vanderveken (1991). On the contrary, others hold, it is grounded on intention or inference-based act like Grice (1989), Strawson (1971), Schiffer (1972), Bach and Harnish (1981), and Kissine (2013). Given these different views, both sides have developed speech act theory in different ways. For instance, the criteria for speech act typology are based on illocutionary force and propositional attitude. Regarding with such tensions, the identification of these types of speech acts in Sasak language is needed. 
The dispute on the role of attitude as the ground for distinguishing the types of illocutionary acts breaks down, since not every act has attitude uttered. For this reason, efforts of developing and exploring the normativity of speech acts have attracted the attention of linguists and analytical philosophers. Searle's identification about the commitment that consists in illocutionary act is under desireindependent reason for action (DIRA) on the bases of conceptual apparatus like direction of fit, intention and the rest. Searle's idea on reasons for action is different from othe classical philosopher (William, 1981; Davidson, 1968). For Searle, the main features of DIRA are naturalistic, intentional, binding, and motivational. This reason refers to commitment that is inherent in performing illocutionary acts.

Dealing with Searle's on commitment, Alston's normative stance and Cuneo normative standing, it is important to identify and examine profoundly the types of normative and moral dimensions of speech acts in Sasak speech community. In addition, having moral dimension is representation of moral values of speech act that might be used for moral or character education.

Their notions have contributed into the normative state of speech act. However, for Searle, the commitment that is consisted in speech acts has nothing to do with moral domain, while in Austin's account the role of social pressures is the main source for the existence of normative stance of a given act. Searle's ignorance of moral issue, a person's point of view, interpersonal communication in the case of commitment like obligation, responsibility in performing speech act is inconsistent with the nature of interpersonal communication, the fundamental principles of morality. Meanwhile, Alston's claim is lacking internal factors in respect to normativity and has no speaker clear-cut point of view generated in speech act performance. Furthermore, Cuneo just analyzed three types of speech acts, assertive, commissive and imperatives, thus his account need to be extended to other types like expressive and declarative. Even the sample provided are limited and based on intuition. For these reason, the types of any category have any subtypes having special normative standing could be extended by analyzing empirical data for proving more adequate description on the normative and moral dimension of speech acts.

Based on these accounts, it is crucial to reanalyze and explore the normative and moral dimensions of speech acts that are universal in nature. Extension and reexamination on the natures of such normativity and morality of speech acts are needed in regard to speech acts' normativity and morality since they are completelycomplex concepts. Furthermore, moral values generated from moral dimension of speech could be identified that might be arena for moral or character education.

In addition, relationship between second language acquisition and speech acts conducted by Blum-Kulka and Ohlstain (1986), Kasper and BlumKulka (1993), Ellis (1992) and others seem to be focused only on the acquisition of particular speech acts such as promise, compliment and so forth as well as its relationship to classroom interaction. The studies are motivated in addressing the importance of improving students'sociolinguistic and communicative competence. However, in reality the problem is not 
only about such competences, but also on student's moral awareness.

Another recent study was conducted by Rakoczy and Tomasello (2009), Lohse, Grafenhein, Behne, and Rakoczy (2014) which focused on children's understanding of speech act normativity. This study seems to be based on psychology and concerns with only the role of direction of fit as a benchmark in analyzing children's understanding of speech act normativity. Their findings indicate the significant relationship of students understanding such normative dimension with the direction of fit as the criterion for the condition of satisfaction in speech act performance. However, in this case, other crucial apparatus like the role of intentionality and normative standing were ignored.

Based on the aforementioned gaps either in normative and moral dimension of speech acts and moral or character education, it is crucial to identify the types of speech acts and its normative and moral dimensions in Sasak language based on Tuan Guru speeches and casual conversations. Moreover, it is essential to extend, explore, and study about the nature of normative dimension of speech acts regarding to types, features, and other concept pertaining to normativity and morality of speech acts such as intentionality, reason for action and second person standpoint. This might be an expected starting point in moral teaching or character education by the means of language institution, which speech morality having moral values is possibly plausible for building children or student's good character.

\section{Theoretical Framework}

Apart from the dispute on the basis of speech act typology, there is promising and crucial dimension of speech acts to be investigated. Such a dimension is related to normative features of speech acts. Few studies are focused on theoretizing core concepts that have been done by Searle (2001), Alston (2000) and Cuneo (2014).

Searle (2001) reveals that normative dimension of speech acts is inherent in nature. Those normative dimensions exist wheneever the speaker and hearer perform speeach acts. For him, that becomes the reason for action according the speech acts performed. Furthermore, that reason for action is commitment-based. Commitments as factitive entities grounded on the conditions of reason for actions have the propositional content and the direction of fit as its logical structure. Thus, such direction imposes the satisfaction of the commitments i.e. if the world matches to the content of the commitments (world-to-mind). Dealing with binding features of such commitments, obligations, it represents S's relations to the speech act performed. In this respect, performing the acts, the agent or S creates himself commitments, obligation, and responsibility.

In the case of desire-independent commitment effecting the secondary reason and motivation, Searle's account emphasizes that the recognition something on a valid reason as the ground for acting is to recognize the factitive entities in terms of $S$ as subject and upward direction of fit. For Searle, such desire-independent reason commitment leading the motivation can be understood by means of relationship between third person and the first person viewpoint, not by way of a matter of causally sufficient condition. From the third point of views, people have a set of institutional structure binding the members by deontic 
structure by their given institution. Meanwhile, in the first person point of view, I myself create such DIRA voluntarily and intentionally (Searle, 2001). In this case, the institutional structure has nothing to do with how we create such deontic power, but only provide the possibility condition for I or agent to perform those commitment and obligation.

However, Searle deny the role of second person standpoint. This is different from Darwall (2006, 2010, 2011, 2013) argue that agent can be morally obliged to do action by way of second person standpoint. For Darwal, the second person standpoint is bound agent practical authority that is related to morality, respect and accountability. Moreover, the second person standpoint represents the relationship between rationality and morality. It seems plausible that in some cases of speech act performance having normative and moral dimension take second person standpoint in order to create practical reason for action. Furthermore, it seem to be more straightforward for agent that has moral obligation to give reactive attitude to the given speech act by $\mathrm{S}$ or $\mathrm{H}$.

Under other conditions, Alston (2001) extends Searle's necessary condition of making promise to form the normative stance of taking responsibility in a given act. Alston's account on the normative aspect of speech act embedded in illocutionary act includes taking responsibility for conditions of satisfaction and rulesubjection acts. The rule is prescribed socially. In this case, R's in performing illocutionary act, it is not individual variation but interpersonal case. Thus for Alston, $\mathrm{R}$ that $p$ is related to give one's utterance normative state in community (Alston, 2001:59). Moreover, in assertion $p$ it represents putting oneself to reproach in the case of being believed that $p$. In this regard, one has nothing to do with expressing his commitment. Rather, it is the way one's behavior fit into systems of rules in speaker linguistic community.

Alston's account represents illocutionary act of promises which speaker takes responsibility for the preparatory condition, the truth, and conventional effect. Furthermore, it describes that IA as rule based. To Alston, utterance made from IA consist in normative fact rather than speaker belief or intention. In addition to Alston extension on description of the condition for other IA type, like order, request, thanks, and excercitive will not be described (see Alston, p. 71--72).

Alston's account on the normative aspect of speech act embedded in illocutionary act includes taking responsibility for conditions of satisfaction and rule-subjection acts. His claim on such states is grounded on a number of candidate analyses in expounding the notion of taking responsibility (R'ing) as follow:

D5. In uttering $S, \mathrm{U}^{\prime} \mathrm{d}^{\mathrm{d}}$ that $p$-in uttering $S, U$ knowingly took on a liability to blame in case of not- $p$.

D6. In uttering $\mathrm{S}, \mathrm{U} \mathrm{R}^{\prime} \mathrm{d}$ that $p-\mathrm{U}$ recognized herself to be rightfully subject to blame , etc., in case of not- $p$.

D7. In uttering $\mathrm{S}, \mathrm{U} \mathrm{R}^{\prime} \mathrm{d}$ that $p$-in uttering $S$, U knowingly took on liability to being incorrect in case of not- $p$.

D8. In uttering $S$, U R'd that $p$-in uttering $S, U$ subjects his utterance to a rule that, in application to this case, implies that it is permissible for $U$ to utter $S$ only if $p$. 
D9. U R's that $p$ in uttering $\mathrm{S}-\mathrm{In}$ uttering $\mathrm{S}, \mathrm{U}$ purports to know that $p$.

D10. U R's that $p$ in uttering $S$ - In uttering $\mathrm{S}, \mathrm{U}$ represents $p$ as being the case.

Alston's aim is to extend Searle's concept on the condition of satisfaction in promising $\mathrm{H}$ to do action. In this respect, he argues that $U$ is not the only one who take responsibility for unsatisfied condition of satisfaction (Alston example see: 54). That is to say, though the condition is satisfied on the basis of Searle's condition 4 or 6 , it remain unsatisfied the condition in $U$ takes responsibility to blame or $U$ recognize to be rightfully subject to blame in case of not- $p$ D5 and D6.

The rule is prescribed socially. In this case, R's in performing illocutionary act, it is not individual variation but interpersonal case. Thus for Alston, $\mathrm{R}$ that $p$ is related to give one's utterance normative state in community. Moreover, in assertion $p$ it represents putting oneself to reproach in the case of being believed that $p$. In this regard, one has nothing to do with expressing his commitment. Rather, it is the way one's behavior fit into systems of rules in speaker linguistic community.

Since in uttering sentence one has no liability by virtue of inadequate belief that $\mathrm{C}$ or incorrect that not-C, Alston suggests another D8 analysis putting one's utterance under subjection to a rule that require $\mathrm{C}$. In $\mathrm{D} 8$, it presents one's utterance that is dependent on the rule in the case of permissible utterance that $p$. By this rule, Alston argues the distinction between objective and subjective obligation can be identified. That is to say one may do something with $\mathrm{C}$ is satisfied, then it is right in objective way. Even if one may do something that
$\mathrm{C}$ is not satisfied, it is wrong in objective way, but it is right in subjective way. That is similar case to when $\mathrm{C}$ is satisfied, but $\mathrm{S}$ does not believe it, then $\mathrm{S}$ does not do it. As a result, one is wrong in objective but right in subjective way. Such phenomena support Alston to claim that blameworthiness and epistemic position that $\mathrm{S}$ is blame to... is a kind of subjective wrongness.

By extension Searle and Alston and on the bases of moral realist, Cuneo (2014) argues that the normative dimensions of speech acts exist by way of agent' having right, obligation and responsibility. These normative standings are altered by agent to $\mathrm{H}$ when performing illocutionary act by uttering locutionary acts. Furthermore, for Cuneo, the normative dimensions of speech acts are also moral. In this respect, his claim is that some of normative features embedded to speech acts are moral since they have moral aspect such as moral right, obligation and responsibility.

The rule is prescribed socially. In this case, R's in performing illocutionary act, it is not individual variation but interpersonal case. Thus for Alston, $\mathrm{R}$ that $p$ is related to give one's utterance normative state in community (ibid.59). Moreover, in assertion $p$ it represents putting oneself to reproach in the case of being believed that $p$. In this regard, one has nothing to do with expressing his commitment. Rather, it is the way one's behavior fit into systems of rules in speaker linguistic community.

Since in uttering sentence one has no liability by virtue of inadequate belief that $\mathrm{C}$ or incorrect that not-C, Alston suggests another D8 analysis putting one's utterance under subjection to a rule that require $C$. In D8, it 
presents one's utterance that is dependent on the rule in the case of permissible utterance that $p$. By this rule, Alston argues the distinction between objective and subjective obligation can be identified (ibid.). That is to say one may do something with $\mathrm{C}$ is satisfied, then it is right in objective way. Even if one may do something that $\mathrm{C}$ is not satisfied, it is wrong in objective way, but it is right in subjective way. That is similar case to when $\mathrm{C}$ is satisfied, but $\mathrm{S}$ does not believe it, then $\mathrm{S}$ does not do it. As a result, one is wrong in objective but right in subjective way. Such phenomena support Alston to claim that blameworthiness and epistemic position that $\mathrm{S}$ is blame to... is a kind of subjective wrongness.

Searle's and Alston's view of normative stance highlighting the speaker, as for Cuneo's either the $\mathrm{S}$ or the $\mathrm{H}$ is bound by the normativity of speech act. Furthermore, the normative dimension encompasses the three related concepts such as right, obligation and responsibility. The normative dimension of speech counts actual or conditional right, actual and conditional generated obligation and responsibility (see Cuneo: 29--43). By these principles, Cuneo's propose is a comprehensive concept of the normative dimension of speech acts, especially in case of assertives, commissives, and imperatives. His notions are more adequate than that of Searle's (2001) and Alston's (2000) arguing that normative featuresonly refer to commitment and responsibility respectively.

In addition, Cuneo had rejected the perlocutionary intention' view believing that some normative dimensions are derived from speech acts. As for his argument, if normative dimensions are generated from speech acts, it is not important to explain the normative theory of speech acts. This position seems to be underpinned by his belief that the performance of speech acts is subject to agents' having right, obligation and responsibility. Such normative standing exist when the $\mathrm{S}$ alter his normative standing to the $\mathrm{H}$ or the audiences.

Another crucial claim by Cuneo is that the normative dimensions of speech acts are moral. In this respect, some normative dimensions have moral aspects. Moral aspect of such normativity in case of assertive, commissive and imperative is the account that is generated for moral right; obligation and responsibility (see Cuneo: 85--97). Based on his statements, it differs from Searle's (2001) view that normative dimensions of speech acts have no relationship with moral dimensions.

His claim that only some of normative dimensions have moral aspects is not in line with Adam's observation that all speech acts have moral dimensions. It seems that such notions based on philosophical positions taken. In Cuneo's view normative dimensions-- as view of a moral realist-- believing in pluralism is based on the assumption that such normative and moral dimensions might be overlapping to the concepts of prudential, legal, and practice based generating right, obligation and responsibility.

However, Cuneo's claim that normative, moral dimensions of speech acts that are embedded in speech acts do not care about other sources of reasons for actions, such as facts and intentional states. Such sources of reasons need to consider to provide an explanatory adequacy of speech act' argument. This 
implies practical reasons that become valid reasons for an action covering relationships of those sources of reasons in speech act performance. His notion also needs to be extended to empirical cases that cover all types and subtypes of speech acts because some might have special ways for performing speech acts and they are successful and nondefective grounded on normative and moral stance.

Dealing with Searle's on commitment, Alston's normative stance and Cuneo normative standing, it is important to identify and examine profoundly the types of normative and moral dimensions of speech acts in Sasak speech community. In addition, having moral dimension is representation of moral values of speech act that might be used for moral or character education.

Based on the theoretical frameworks, this study combine Searle, Alston and Cuneo notion on the normative and moral dimension of speech acts. Such integrated frameworks are used as lens to look at the nature of normative and moral dimension of speech acts.

\section{Research Method}

Approach used in this study is pragmatics, namely speech act analyses. In this respect, the principle of analyzing linguistic data for speech act used illocutionary act element: illocutionary force and the propositional contents as the approach to categorize different types of speech acts. Searle and Vanderveken (2005) account on illocutionary force components was applied to categorize types of illocutionary acts of Tuan guru speeches and casual conversation.
Furthermore, other approaches are crucial in analyzing and examining the types and natures of the normative dimensions of speech acts, namely, philosophy of the mind, philosophy of action, and philosophical ethics. These approaches combined are commonly used in analytical linguistics, especially in analysis of speech act normativity.

To collect the data, observation and voice recording method are applied. The methods chosen covered the speech act phenomena, dimensions of speech act normativity and morality grounded on the universality principle of analyzing double structure $\mathrm{F}(\mathrm{p})$ and set of successful conditions of each act. Spoken data from Tuan Guru speeches in formal setting and casual conversations in informal setting in South Sikur village using Meno-mene dialect were collected by observing and recording. Observation by recording was done for about 3 months. Tuan guru speech 1 was recorded on $5^{\text {th }}$ August 2015 with duration 12 minutes 58 second. Tuan guru 2 was recorded on $9^{\text {th }}$ September 2015 with duration 43 minutes and 49 second. The last, casual conversations were recorded in $12^{\text {th }}$ October 2015 with duration 1 hour 23 minutes. Moreover, data recorded from Tuan Guru speeches and casual conversations in South Sikur village were conducted from August until October. The recorded data are transcribed into English.

\section{Discussion}

\subsection{Normative Dimensions of Speech Acts}

Normative features of the types of illocutionary acts are derived from the normative standing of agents. Normative dimensions are embedded in speech acts and are generated from 
these agents' as having right, obligation and responsibility. These normative features lead the normative standing of the agents (the $\mathrm{S}$ and the $\mathrm{H}$ ). Such normative standing by agents are generated from performing illocutionary acts and the ways of locutionary acts. The followings are the results and types of normative features those that support how such normativity is generated in performing speech acts. The followings are subtypes of the assertive found in lines (1--14):

(1)

TG 1: Ndeq araq sarat dengan saq

rujuq. (affirming)

No-D there-adv requirement-n people-n who-pron reconciliation

There is no requirement for people to reconcile.

TG1: Sekalipun pegawean halal, saq aren beseang nuq kurang bagus. (describing)

Though-P action-n allowed-A, What-RP called-v divorce-n not- good-A.

Though it is an allowed action, what is called divorce is not good.

TG1: Lamun wah rujuq nuq wajib beng hak untuk senine. (explaining)

If-conj already-adv reconcile-v obligatory-A give- $v$ right-n for-P wife$\mathrm{n}$

If a husband has been reconciled, it is obligatory to give the right for his wife
(4)

TG 2: Ndeq arak dengan ndek mele bagus leq dunia niq. (concluding)

No-adv there-adv not-adv want-v good-A in-P world-n this-D

Everyone wants to be good in this world.

TG2: Due model dengan berjamaah. (describing/categorizing)

Two-D model-n pray together-PV

There are two models of praying together.

\section{Casual conversation (CC)}

(6)

C: Kan mako gecok talet wayah nuq. (asserting)

Cut tobacco-NP plant-v parent-n

Cutting the tobacco planted by your parents.

(7)

A: Mahen mako gecok. (stating)

Expensive-A cut tobacco-NP

Cutting tobacco is expensive.

(8)

A: Timak mako gecok, mun selamet

jaq, beleq mauk keping endah. (remarking)

Though-conj cut tobacco-NP, Ifconj successful-A, much-D money-n

Though it is just cutting tobacco, if it is successful, we earn much money.

(9)

\section{A: Ndeq iniq ngkah saqit semeniq}

onos anuq geres julun wiq nuq.

(telling)

Not-adv can-mod heal-v back-n beacause of-PP carrying-ger sand-n day before yesterday 
My back cannot heal because I was carrying away the sand the day (10)

before yesterday.

\section{A: Saq tokon-tokon meni ampoq}

berirap. (telling/informing)

When-adv sitting-ger felt-v

When I am just sitting like this, it feels painful.

E: Nun, jaq mulen. (agreeing)

Yes-adv it-pron does-mod

Yes, it does.

A: Dunie nik congok congo::.:k lat to bih mate. (warn)

World-n this-D sit-v later-adv allpron die-v

Just sit now, in this world later we all die.

D: Sugih jari belian nane. (remark)

Rich-A be-aux dukun-n now

It is rich to be a dukun now.

A: Mun begadang jaq becat kurang

daraq. (concluding)

If-conj stay up-PV high-adv low-A blood-n

If you stay up, it makes low blood pressure.

In performing an assertion as in line (1--14), the speaker has a right to assert that (p), the $S$ has an obligation to the truth of (p) and so on. In this case, the $S^{\prime}$ right, obligation, responsibility, and the $\mathrm{H}^{\prime}$ right are both generated from agents altering the normative standing. Performing assertion involves intentional states (beliefs) of the $\mathrm{S}$ and the $\mathrm{H}$, as well as normative dimensions generated from agents having right, obligation and responsibility. In the performance of assertion as in lines (1-14), the followings are normative features of assertions:

1. The $\mathrm{S}$ has an obligation to his argument asserted in the utterance

2. The $\mathrm{S}$ is responsible for his position if the assertion is failed to obtain the truth of proposition

3. The $\mathrm{H}$ has the right to correct/ blame if the $\mathrm{S}^{\prime}$ statement is not true

4. The $\mathrm{H}$ has an obligation to believe the S' claim (TG)

\section{Imperatives}

(17) Lalo ngeraos pacu-pacu.

(suggesting)

Go-v talks-n truly-adv

Go to who talks truly.

(18) Mun talaq telu, ndeqte kanggo

tulakang saq ndeq man saq nine nuq merariq

if-con third-A divorce-not-adv

allowed reconciling- $v$ before-P

woman-n marry-v

malik bekeq dengan lain.

(prohibiting)

again-adv with-P Another-pron

It is not allowed to reconcile

with a woman and get

remarried with the same man if it was the third divorce.

(19) Wajib dore nae dengan nine mun ragu penggitan atau ndeq naedemen sujud. (order) Obligatory-A leg-n woman-n if-conj uncovered or-cond nor-adv

It is obliged for women to check her legs if she is worried whether her legs are covered or not during bowing.

(20) Mun makmum nuq redo tepebelok ayat, sunat imam nuq pebelok ayat. (order) 
If-conj congregation-n willingA lengthen- $v$ verse- $n$, sunnah- $n$ imam-n lengthen- $v$ verse- $n$ If the congregation is willing the verse to be lengthened, it is sunnah for imam to lengthen the verse.

(21) E:// angetang aik Awe tan! (order) Boil-v water-n Boil the water, Awe!

(22) C: Coba orah angkaq! (suggesting)

Try- $\mathrm{v}$ massage- $\mathrm{n}$

Try to get the massage!

(23)A: Masih ngoven mako to? (question as request) Still-adv cutivate-v tobacco-n Do you still dry tobacco in the oven?

D: Masih

Still-adv

still

(24) A: Dendeq ndeq e gawek tie. (order/prohibiting)

Not-adv do-v that-pron

Don't do that!

(25) A: Jagaq kakenan kance pikiran. (suggesting)

Control-v food-n and-conj thought-n Control food and thought!

(26) D: Endeng tulung beliang gorengan aloh! please-exc buy-v fried food-NP Please, buy fried food!

(27) F: enteh awe milu lalo meli. (inviting) Let-v Awe-PN join-v buy-v Awe, let me join to buy.

(28) A: Apika:::n entan= laun tegoroke sik dengan. (advise)

Careful-A later-adv slaughter-v by-P other-pron

Be careful! You will be slaughtered byothers.
In case of imperatives as in lines (17--28), there are different ways of acquiring normative features. For instance, in lines (18--20), the order given is performed by TG invoke their standing power as a religious person. To be successful, the performance needs a specialized normative standing of the TG by cultural and social stipulation. The special feature of order given by the TG in line (18), the $S$ lays an obligation not only to the $\mathrm{H}$ but also to the $\mathrm{S}$ to do $p$. To see how that order put a duty on the $\mathrm{S}$ himself is from a second person's standpoint that will be discussed further in the next unit. The normative standing generated in performing the speech act is by the way of the agent's normative standing. The $S$ has the right to put an obligation on himself on the Hto do the action in the future (the TG' order). The followings are normative features in performing commisive:

1. The $\mathrm{S}$ has a conditional right to get the $\mathrm{H}$ do something (authority, prudential, practice based).

2. The $\mathrm{S}$ has a conditionally generated obligation to believe that the $\mathrm{H}$ has the ability, possibility and willing to do the action.

3. The $\mathrm{S}$ has a generated obligation to believe that the $\mathrm{S}$ has the ability, the possibility and willing to do the action.

4. The $S$ is responsible to proceed again if the $S$ has no belief that the $\mathrm{H}$ has the ability, possibility and willingness to do the action.

5. The $\mathrm{S}$ is responsible to be corrected if the $S$ has no belief of his ability, possibility and willingness to do the action.

6. The $\mathrm{H}$ has a conditional right to correct the $\mathrm{H}$ is there is no belief of 
his ability, possibility and willingness to do the action.

7. The $H$ has an actual generated obligation if he believes he has the ability and possibility to do the action (the order).

8. The $\mathrm{H}$ has a conditionally generated obligation if he believes in his ability, possibility and willingness to do that action (suggestion, inviting, giving advice, and making a request).

\section{Expressives}

(29)

TG1: Assalamualaikum warrahmatullahibaraqatuh. (Greet/pray)

Peace be upon you!

TG1: Tunas maaf lamun araq salaq dalam atur tiang. (apologize)

Beg-v pardon- $n$ if conj there-adv mistake-n in-P my speech-NP

$\mathrm{I}$ beg your pardon if there is (31) mistake in my speech.

TG2: Yang tiang hormati bapakbapak/ibu-ibu. (respect) That-adv I-pron respect-v His excellence $\mathrm{mr} / \mathrm{mrs}$.

TG2: Mudah-mudahan arak manfaat. (well-wish/pray) hope-v goodness-n I wish there is goodness.

TG2: Terima kasih atas perhatiannya. (thank)

Thank-excla for-P attention-n your

Thanks for your attention.

Casual conversations (CC) (34)

A: ee sakit ne. (painful)

Painful-A it-pron
C: Mudah mudahan saq pade tekican selamet. (well-wish/pray) May-mod all-pron safe-n May all be safe.

A: $\quad$ Sale sale doang tie. (criticize) wrong-A just-adv it-pron It is just wrong.

C: Kesengeh ambun parfum, Gus. (compliment)

Fragrant-A smell-v parfume-n Your perfume smells so fragrant, Agus.

Regarding performing expressives as in lines (29--37), the $\mathrm{S}$ has the right to express his attitude to the $\mathrm{H}$. The $\mathrm{S}$ has an obligation to the truth of the psychological state expressed and the rest is not only derived from the act itself, but also from agents: having right, obligation, and responsibility. The followings are the normative properties of performing expressive.

1. The $\mathrm{S}$ has the right to express something to the $\mathrm{H}$.

2. The $\mathrm{S}$ has an obligation to the truth of the psychological states expressed.

3. The $\mathrm{S}$ is responsible for failing the truth of psychological states expressed.

4. The $\mathrm{H}$ has an obligation to respond to the S'psychological states.

5. The $\mathrm{H}$ has the right to express reproach/ correcting the $\mathrm{S}$ is he fails to fulfill the truth of psychological states expressed. 


\section{Commissive}

(38)

B: Lemak bian jam-jam 7 lalo bejango ojoq Selong. (promising)

Tomorrow-adv evening-adv time-n go-v look out-PV to-P Selong-n

Tomorrow evening we go to look out to Selong around 7.

D: Aoq wah. (accepting/confirming) ok-adv

OK.

(39)

$\mathrm{B}$ : Bareh e ngeronde kance batur-

batur nuq. (promising)

Tonight-adv I-pron will-mod patrol with-P friends-n

Tonight, I will patrol with my

friends.

B: ed pade sugun bareh ngeronde тепи?

Will-mod you-pron all-pron patrol-v Will you all patrol tonight?

C: Aok. Bareh ke sugun malik jam-jam 12. (promising)

Yes-adv, tonight I-pron will-mod go out-PV again-adv time-n

Yes, I will go to patrol around 12 tonight.
$\mathrm{A}: \quad=a o k$
Yes-adv
Yes.

B: Mun sehat jaq, e puase seminggu.
If-conj recover-v, I-pron fast-v a

week-adv

If I recover, I will fast for a week.

In case of commisive as in lines (38--40), the alteration of normative standing in performing a promise generates: the $S^{\prime}$ right to put himself in an obligation to do the action; the $\mathrm{S}$ and the $\mathrm{H}$ have an obligation to do them $\mathrm{p}$ (for collective-intention and wecommitment), the $\mathrm{S}$ has an obligation to do the action $\mathrm{p}$ (for I intention and Icommitment) and so on. Some of normative features in the performance of commisive are:

1. The $\mathrm{S}$ has the right to put a promise obligation on himself if the condition in the clause is fulfilled (I-commitment).

2. The $\mathrm{S}$ and the $\mathrm{H}$ has the right to put an obligation on themselves for their promise (we-/icommitment)

3. The $\mathrm{S}$ has an obligation to do as promised in the proposition.

4. The $\mathrm{S}$ and the $\mathrm{H}$ have an obligation to do the action in the future as promised in the proposition.

5. The $\mathrm{S}$ is responsible for correcting, blaming if the his promise fails to be fulfilled. (involving his intention).

6. The $\mathrm{S}$ and the $\mathrm{H}$ are responsible for blaming if they fail to fulfill the promise.

7. The $H$ has the right to correct the $\mathrm{S}$ if the promise is not being fulfilled. 
8. The $\mathrm{S}$ is obligated to control/ reproach if he fails to fulfill his promise.

The generated or derivative nature of such normative dimensions also occur in declarative.

\section{(41) B: Kafir uah (ahmadiyah). (naming) \\ Unbeliever-n \\ They are unbelievers.}

By the way of performing declarative as in line( 41 ) the $S$ has the right to declare and alter the states of affairs. The $\mathrm{S}$ has an obligation to alter the states of affairs. As indicated in line (41), the S has no right to declare such a status alteration. Hence, the declarative example in this study is successful, but defective. Some normative types of declarative:

1. The $\mathrm{S}$ has the right to alter the states of affairs being declared.

2. The $\mathrm{S}$ has an obligation to alter the states of affairs.

3. The $\mathrm{S}$ has a responsibility if the requirement in the declaration is not fulfilled.

4. The $\mathrm{H}$ has the right to correct/blame if the $\mathrm{S}$ has no authority to declare.

Intentionality has a crucial role for the describing agent's mental state in performing speech acts. The reason for this is that intentionality has a psychological mode and propositional content. Furthermore, intentional states involved in speech acts are représentations of its condition of satisfaction and the direction of fit. In performing assertion as in lines (1--14), the speaker asserts the truth of the proposition grounded on his belief. The speaker's belief is the intentional state of assertion. Since intention has a psychological mode (S) and representation content (r) or S (r). As in line 1 , the $S$ asserted that there is no requirement for reconciliation. In this case, the $\mathrm{S}^{\prime}$ belief as psychological mode or intentional state in assertion impose its direction of fit, while the representation content impose the condition of satisfaction (truth) on the condition of satisfaction ( $S^{\prime}$ utterance). For this above reason, the assertion is true if the propositional /representation content is true. In case of the belief, it imposes the direction of fit, the content of assertion matches reality. So assertion has an intentional state, direction of fit and condition of satisfaction.

In case of performing imperatives as in lines (17--28), the intentional state is the $S^{\prime}$ desire or want. For instance, in line (21), the $\mathrm{S}$ wants the $\mathrm{H}$ to boil water. The $\mathrm{S}$ wants something by ordering the $\mathrm{H}$ to do that $p$. The condition of satisfaction is imposed by the representation content viz. The $\mathrm{H}$ obeys the order. Meanwhile, the direction of fit imposed by its psychological mode, the $\mathrm{S}$ desire or want is that the $\mathrm{H}$ do the action $p$ to match the $S^{\prime}$ order. The properties of condition of satisfaction and direction of fit to other types of imperatives like suggesting, request, inviting, advising are similar to giving an order.

Another type of IA that has the same direction of fit with imperative is commissive. The direction of fit of commissive as in lines(38-40) is world to word. It is determined by its representation content. In the performance of commissive, its intentional states are intentions. This intentional state imposes the direction 
of fit of commissive. Meanwhile, the condition of satisfaction (COS) of commissive in case of giving a promise is the $\mathrm{S}^{\prime}$ fulfillment of his intention to do $p$.

In regards to expressive as in lines (29--37), the performing of expressive has no intentional state expressed. Thus, expressive has no either direction of fit and condition of satisfaction. Rather, the truths of psychological states expressed are presupposed to the given belief. For instance, in line (36) the $\mathrm{S}$ criticizes that it is wrong for the hearer to be fake shaman. This expression involves the $\mathrm{S}^{\prime}$ belief that is $p$. This indicates that such an expression is grounded on a given belief as the presupposition of the truth of propositional states expressed.

As for the last type, performing declarative in line (38), the intentional state is either a belief, a desire or a want to alter the state of affair. Thus, declarative has double direction of fit. In this case, to be successful, the $S$ has to have a belief $(\downarrow)$ and his desire $(\uparrow)$ to change a status. These double intentional states make a declarative to have double direction of fit $(\uparrow)$.

\subsection{Reason For Performing Speech Acts}

The importance of reasons for action is completely related to giving the relationship of facts, human mind, and normative fact to the action. Reasons for action in terms of performing speech acts are grounded on facts, intentional states and normative entity (or factitive entity borrowed from Searle). In performing speech acts, the reasons for action include all the factitive entities or at least intentional states and normative entity. The followings are the results of reasons for action found in the study in terms of factitive entity as a valid reason for action.

\section{Assertive}

Reasons for performing assertion found include facts, intentional states and normative facts. For instance in line

(1) Ndeq araq sarat dengan saq rujuq. (asserting)

No-D there-adv requirement-n people-n who-pron reconcilation 'There is no a requirement for people to reconcile.'

Intentional state:

- $\mathrm{S}$ believe that $p$ is true.

So asserting $\rightarrow \operatorname{Bel}(\mathrm{p})$

Normative facts:

- The $\mathrm{S}$ has an obligation to believe that $\mathrm{p}$ is true.

- The $S$ has an obligation for making the $\mathrm{H}$ believe that $\mathrm{p}$ is true.

- The S lays an obligation on the $\mathrm{H}$ to make him believe that $\mathrm{p}$ is true.

In this case, the assertion performed by TG includes intentional state and a normative fact as the reasons for action in performing it. These reasons for action are similar to other subtypes of assertive as in lines (2--14) involving both reasons for action. However, as indicated in lines $(5,8,14)$, the truth of proposition is conditional since the its truth is subject to fulfillment of the if-clause. However, the normative fact that put an obligation on either the $\mathrm{S}$ or the $\mathrm{H}$ believing that the truth of $p$ not conditional. Thus, the $S^{\prime}$ belief as intentional states that the truth of proposition is conditional is not the same with the $S^{\prime}$ obligation to believe that $\mathrm{p}$ is true or the $\mathrm{S}$ has an 
obligation to make the $\mathrm{H}$ believe that $\mathrm{p}$ is a conditional truth.

\section{Imperative}

As indicated in lines (17--28), to perform the subtypes of imperative is the most reason for action such as intentional states and normative facts. Its intentional states and normative fact of given subtypes as follow:

\section{7)}

TG1: Lalo ngeraos pacu-pacu.

(suggesting)

Go-v talks-n truly-adv

Go to talks truly.

\section{Intentional states:}

- $\quad$ The $\mathrm{S}$ wants the $\mathrm{H}$ to do something (p).

So suggesting $\rightarrow \mathrm{W}$ (p).

Normative facts:

- The $\mathrm{S}$ has an obligation to the $\mathrm{H}$ to do the action (p).

- The $\mathrm{S}$ and the H both have an obligation to do the action (p).

- The $\mathrm{S}$ and the $\mathrm{H}$ are responsible for not to do the action (p).

(18)

TG1: Mun talaq telu, ndeqte kanggo

if-con third-A divorce-not-adv allowed

tulakang saq ndeqman saq nine nuq reconciling-v before-P woman-n marry-v malik bekeq dengan lain. (prohibiting)

again-adv with-P Another-pron

'It is not allowed to reconcile before the woman get married with another if it is the third divorce.'

\section{Intentional states:}

The $S$ believes that $p$ is true and want the $\mathrm{H}$ to do something (p). So prohibiting $\rightarrow \mathrm{Bel}(\mathrm{p}) \& \mathrm{~W}(\mathrm{p})$. Normative facts:
- The $\mathrm{S}$ has an obligation to the $\mathrm{H}$ to do that (p).

- The $S$ and the $H$ have an obligation to do that (p).

- The $\mathrm{S}$ and the $\mathrm{H}$ are responsible for not to do that (p).

(19)

TG2: Wajib dore nae dengan nine mun Obligatory-A leg-n woman-n ifconj ragu pengitan atau ndeq nae doubt-adj uncovered or-cond nor$\mathrm{adv}$

demen sujud. (order)

during-prep sujud-n

'It is an obligation for a woman to check her legs if she is worried whether her legs are covered or not during sujud.'

Intentional states:

- The $S$ believes that (p) and want the $\mathrm{H}$ to do that (p).

So ordering $\rightarrow \operatorname{Bel}(\mathrm{p}) \& \mathrm{~W}(\mathrm{p})$.

Normative facts:

- The $\mathrm{S}$ has an obligation for the truth of that (p)

- The $\mathrm{S}$ lays an obligation tothe $\mathrm{H}$ to do that (p).

- The H (woman) has an obligation to do that (p).

- The $\mathrm{S}$ is responsible for the truth of that (p)

- and $\mathrm{H}$ is responsible for not to do that (p).

21)

E:// Angetang aik Awe tan! (order)

Boil-v water-n

Boil water, Awe!

Intentional states:

- The $\mathrm{S}$ wants the $\mathrm{H}$ to do that (p). So order $\rightarrow W(p)$.

Normative facts:

- The $\mathrm{S}$ has the right to lay an obligation to the $\mathrm{H}$ to do that (p). 
- The $\mathrm{H}$ has an obligation to do that (p).

- The $\mathrm{H}$ is responsible for not to do that $(\mathrm{p})$.

\section{Commissive}

Performing speech acts like making a promise or making a demand the $S^{\prime}$ intention is in order to be successful and a sincere promise. However, it is not sufficient to explain the reason for action. The followings are reasons for action when performing a promise as in lines $(38,40)$.

(38)

B: Lemak bian jam-jam 7 lalo

Tomorrow-adv evening-adv time-n go-v

bejango ojoq Selong. (promising)

look out-PV to-P Selong-n

Tomorrow evening we go to look out for Selong around 7.

D: Aoq wah. (accepting/confirming) ok-adv

$\mathrm{OK}$

Intentional states:

- The $\mathrm{S}$ and the $\mathrm{H}$ believe that it is possible to that $p$ i.e to go to look out and $S$ intend to $(\mathrm{p})$.

So we-promising $\rightarrow \mathrm{S} \& \mathrm{H}$ Bel $(\diamond$

p) \& W (p).

Normative facts:

- The $\mathrm{S}$ and the $\mathrm{H}$ have an obligation to their belief that is possible to do (p).

- The $\mathrm{S}$ and the $\mathrm{H}$ have an obligation to do that $\mathrm{p}$.

- The $\mathrm{S}$ and the $\mathrm{H}$ are responsible for not being (p) and not want to do (p).

- The $\mathrm{S}$ and the $\mathrm{H}$ have theright to remind if the $\mathrm{S}$ or the $\mathrm{H}$ do not keep their promises.

40)

B: Mun sehat jaq, e puase seminggu.
If-conj recover-v, I-pron fast-v a week-adv

If I recover, I will fast for a week.

\section{Intentional states:}

- The $S^{\prime}$ belief is it is possible for him to do (p) and wants to do that (p).

So, I-promising $\rightarrow$ S Bel $(\diamond p)$ and $\mathrm{W}(\mathrm{p})$ if (q).

Normative fact:

- The $S$ has an obligation if his belief on that ( $p$ ) if $q$ (if I recover) is fulfilled.

- The $\mathrm{S}$ is responsible to his belief on the truth of being not $(\mathrm{p})$.

Based on lines 38 and 40 , the reasons for action differ in terms of intentional states and normative entity. In line (39), its intentional state is a collective belief and wants to do that (p). Furthermore, its normative entity is a collective obligation and responsibility. On the contrary, as in line (40), its intentional state is an individual belief and wants to do that (p). Meanwhile, its normative entity is an individual obligation and responsibility. These indicate that it is the We-intention and obligation (commitment) in line (39), while it is Iintention and I-obligation in line (40). In addition to case line (40), the content of proposition is also conditional. In other words, for its intentional state, the $\mathrm{S}$ believes that it is possible to do that (p) and wants to do that (p) if conditional sentence is fulfilled (if (q).

\section{Expressive}

Dealing with expressive, reasons for action include facts, intentional states and normative entity. The followings are reasons for action of expressive. The cases of expressive are in lines (29--37) 
(30)

G1: Tunas maaf lamun araq salaq dalam Beg-v pardon-n if conj there-adv mistake-n in-P atur tiang. (apologize) my speech-NP

I beg your pardon if there is mistake in my speech.

Intentional states:

- The $S$ believes to do that $\mathrm{p}$ and wants $(\sim p)$.

So, apologizing $\rightarrow \mathrm{Bel}(\mathrm{p})$ and $\mathrm{W}$ ( p).

Normative fact:

- The $\mathrm{S}$ is responsible for that $(\sim \mathrm{p})$

TG2: Yang tiang hormati bapak-

That-adv I-pron respect-v bapak/ibu-ibu. (respect)

ladies and gentleman-pron

His excellence $\mathrm{mr} / \mathrm{mrs}$

Intentional states:

$\mathrm{S}$ believes to the truth of (p) and want to that (p).

So, respecting $\rightarrow$ Bel (p) \& W (p) (33)

TG2: Terima kasih atas perhatiannya. (thanking)

Thank-excla for-P attention-n your

Thanks for your attention.

Intentional states:

- The $\mathrm{S}$ believes that the $\mathrm{H}$ has done something beneficial for the $\mathrm{S}$ and wants to that $(\mathrm{p})$.

So thanking $\rightarrow \operatorname{Bel}(p)$ and $\mathrm{W}(\mathrm{p})$

Normative fact:

- The $\mathrm{S}$ has an obligation to believe that (p) and to do that (p). (35)

C: Mudah mudahan saq pade tekican

May-mod all-pron

selamet. (well-wish-pray) safe-n

May all be safe.

Intentional states:

- The $\mathrm{S}$ believes in a future truth of an event (p) and to that (p).

So, praying $\rightarrow \mathrm{Bel}(\mathrm{p})$ and $\mathrm{W}(\mathrm{p})$

Normative fact:

- The $\mathrm{S}$ and the $\mathrm{H}$ have a collective obligation to the truth of something p.

(36) A: Sale sale doang tie. (criticize)

wrong-A just-adv it-pron

It is just wrong.

\section{Intentional states:}

- The $S$ believe to that ( $p$ ) is not good and don't want the $\mathrm{H}$ to do that (p) and believing someone is responsible for such and such (p).So, criticizing $\rightarrow$ Bel (p) and $\mathrm{W}$ $(\sim \mathrm{p})$ and $\mathrm{Bel}(\mathrm{H}$ is responsible if that (p))

Normative fact:

- The $S$ has an obligation for the truth of (p).

(37)

C: Kesengeh ambun parfum,Gus. (compl)

Fragnant-A smell-v parfume-n

Your perfume smells so fragrant, Agus.

\section{Intentional states:}

- The $\mathrm{S}$ believes to that (p) and wants to that $(\mathrm{p})$

- So, compliment $\rightarrow$ Bel (p) and W (p)

Normative fact:

- The $\mathrm{S}$ has an obligation for the truth of $(\mathrm{p})$.

As indicated in line (30) above, the reasons for action involves intentional states (believing (p) and want $(\sim p)$. in other words, the reason for action is a belief that it is possible for him to make a mistake during the speech and he does not have the 
intention to make one. It means the $\mathrm{S}^{\prime}$ belief on the truth of psychological state is expressed, presupposed the truth of states. Furthermore, the reason for action derives from normative that is the $\mathrm{S}$ has an obligation to believe that is possible for him to make a mistake. As other lines above indicated, most subtypes of expressive, the reason for action is either intentional states or normative entity in performing it.

\section{Declarative}

In these types, declarative is a unique type of speech having double directions of fit and without sincerity conditions. The following is the only example of declarative found in casual conversation.

B: Kafir uah (ahmadiyah). (naming) Unbeliever-n

They are unbelievers.

Fact:

- Ahmadiyah violate the Islamicprinciples

Intentional states:

- The $\mathrm{S}$ believes that the Ahmadiyah follower violates the essence ofIslam' principles and the $\mathrm{S}$ wants to alter its status by calling the person 'unbeliever. So, Naming $\rightarrow$ Bel (p) \& W (p)

\section{Normative fact:}

- The $\mathrm{S}$ has an obligation to the truth of (p).

- The $\mathrm{S}$ is responsible for the belief if it is not true

In this case, the $S$ succeeded to state his belief (p), but the $S$ failed to change the status of Ahmadiyah based on his wants. This indicates that the reason for the $\mathrm{S}$ to perform it is geounded on the fact violation of the Islamic principle by ahmaiyah; and his intentional state viz. belief to that (p) and wants to change the state of Ahmadiyah by naming him as an unbeliever; and his normative reason is his obligation to the truth of that $p$.

In order to be successful in declarative, the $S$ presuppose the institutional fact existing by the way of collective recognition and acceptance. Using institutional facts (religious board, school etc), we collectively impose the status function of someone or an institution. These facts have standing power or authority of generated standing right for certain people depending on contexts. This is the only way when a declarative can be successful and non-defective. Thus, in line (40), the $S$ who has no power or authority included three sources of reasons, but still failed to name a collective belief. Furthermore, that failure is caused by $\mathrm{S}$ declaration grounded only on his individual belief and desire to that $\mathrm{p}$.

\section{Conclusion and Suggestion}

All normative dimensions of any subtypes of illocutionary acts are moral. Such moral aspects include actual and conditional moral right; actual and conditional moral obligation; and actual and conditional moral responsibility. However, in case of comissive and declarative, the subtypes found are so limited that it is far from an adequate description of its normative and moral dimensions.

Above all the natures of normative and moral dimensions are generated; they're related to other factitive entities like facts (brute and institutional facts) and intertwined with the practical reason foraction. 
Generative characteristic of normative and moral dimensions are results from an agent having right, obligation, and responsibility. Actions are altered by an agent when performing speech acts for the $\mathrm{H}$. Furthermore, intentional states include belief, want, and intention corresponding to types of speech acts those are also influenced by fact, normative and moral reason for actions. In other words, such factitive entities are both internal and external.

Finally, the moral dimensions of speech acts having moral values might be an arena for moral or character education. If moral aspects exist in speech acts, there are moral values generated. Thus, as indicated in findings and discussion a number of moral values pertains to any types of speech acts such as honesty, credibility, truth, obedience, self-respect, concern for others, and the rest could be taught to children or students. In this case, teachers, family, and community need to cooperate to build a moral character by ways of giving an understanding on a set of essential conditions of speech acts, including moral dimensions embedded to speech acts. The motivation for taking such morality of speech acts is the arena of moral and character education as for universality, accessibility, and practical reasons. In addition, moral values embedded in speech acts cover the core values that are necessarily to be addressed in character education such as reasoning, attitude, and good behavior.

Based on the limited concern of the study, it is needed to do further studies on analyzing the illocutionary force indicating device of different languages, indirect speech acts and other context of speech acts for increasing description and explanation on the basis of empirical linguistics.
Second, the normative and moral dimensions of speech acts are complex things, therefore any relevant concepts to those notions like freedom, rationality, motivation, and the rest are in need of further scrutiny in order to have a more comprehensive argument. Finally, the moral values of speech identified are far more from adequate identification in terms of modeling, principles, assessment, and management. Those need further analysis to provide an adequate foundation of moral and character education in every context and discipline.

\section{References}

Alston, W.P. (2000). Illocutionary act and sentence meaning, Ithaca: Cornell University Press.

Austin, J. L.(1962). How to do things with words, Oxford: Clarendon Press.

Bach, K. \& Harnish, R.M. (1981). Linguistic communication and speech acts. Cambridge, MA. MIT Press.

Ball, B. (2014). Speech acts: natural or normative kinds? The case of assertion, Mind and Laguage 29, pp. 336--350.

Blum-Kulka, S \& House, J. (1989). Cross-cultural and situational requesting behavior. In S. BlumKulka, J. House, \& G. Kasper (Eds.), Cross-cultural pragmatic: Request and apologies (pp.123-154). Norwood, NJ: Ablex. 
Blum-Kulka, S., \& Olshtain, E. (1986). Too many words: length of utterance and pragmatic failure: Studies in second language acquisition, 8, 47--61.

Cuneo, T. (2014). Speech and morality. New York: Oxford University Press.

Davidson, D. (1973). Freedom to act. In T. Honderich (ed.) Essay on freedom of action, London, Henley, and Boston: Routledge \& Kagan Paul, pp.153-4

Darwall, S. (1998). Philosophical ethics, USA: Westview Press.

Darwall, S.(2013a). Morality, authority, and law: Essays in second-personal ethics 1. UK: Oxford University Press.

Darwall, S. (2013b). Honor, history, and relationship: Essays in second-personal ethics 2. UK: Oxford University Press.

Ellis, R. (1992). Learning to communicate in the classroom: a study of two language learners' request. Studies in second language acquisition, 14, 1--23.

Grice. H. P. (1989). Studies in the way of words, Cambridge, MA: Harvard University Press.

Habermas, J. (1998). On the pragmatic of ommunication. Maeva Cooke (ed), USA: MIT Press.

Harnish, R. (2005). Commitment and speech acts, Philosphica 75 pp. $11--41$.
Harnish, R and Plunze, C. (2006). Illocutionary rules, Pragmatics and Cognition. 14 (1), 47--52.

House, J \& Kasper, G. (1987). Interlanguage pragmatic: requesting in a foreign language. In W. Lorscher \& R. Schulze (Eds.), Perpectives on language and performance. Festschrift for Werner Hullen (pp.1250--1288). Tubingen: Gunter Narr.

Kasper, G \& Dahl, M. (1991). Research methods in interlanguage pragmatics. Studies in second language acquisition, 13, 215-247.

Kissine, R. M. (2013). From utterances to speech acts. Cambridge: Cambridge University Press.

Tshohatzidis, S. L. (2007). John Searle's philosophy of language; force, meaning, mind, Cambridge: Cambridge University Press.

Plunze, C and Harnish, R. M. (2004). Normativity and speech acts: On Alston's illocutionary rules. In J. Marek and M. Reicher (Eds). Experience and analysis: papers from the 27th international Wittgenstein symposium Kirchberg am Wechsel, Austria.

Rakoczy, H and Tomasello, M. (2009). Done wrong or said wrong? Young children understand the normative direction of fit of different speech acts. Cognition, 113, 205--212.

Sbisa, M. (2001). Illocutionary force and degrees of strength in language use, Journal of Pragmatics 33: 1791--1814. 
Searle, J. R. (1969). Speech acts. Cambridge: Cambridge University Press.

Searle, J. R (1979). Expression and meaning. Cambridge: Cambridge University Press.

Searle, J. R. (1968). Austin on locutionary and illocutionary act, philosophical review, 57 405-424.

Searle, J. R. (1983). Intentionality, Cambridge: Cambridge University Press.

Searle, J. R. and Vanderveken, D. (1985). Foundation of illocutionary logic, Cambridge: Cambridge University Press.

Searle, J. R. (2001). Rationality in action, Cambridge, Mass: MIT Press.

Searle, J. R. (2010). Making the social world: The structure of human civilization. New York: Oxford University Press.

Schiffer, S. (1972). Meaning, Oxford: Oxford Univeristy Press.

Strawson, P. F. (1971). Intention and convention in speech acts. The philosophy of language, ed. by J. R. Searle, 23--38. London: Oxford University Press.

Tsohatzidis, S.L. (1994). Foundation of speech act theory, London: Routledge.

Vanderveken, D. (1991). Meaning and Speech Acts. Volume I: Principles of Language Use, Cambridge: Cambridge University Press.
Vendler, Zeno. (1972). Res cogitans: An essay in rational psychology. Ithaca: Cornell University Press.

Von Wright, G. H. (1963). Norm and action. London: Routledge \& Kegan Paul PLC.

William, J. (1981). The principles of psychology, 2, Dover pp. 48 